\title{
Por que o jornalismo precisa de doutores?
}

Investir em programas de pós-graduação fará com que a nossa atividade se pareça mais com uma profissão e menos com um ofício.

\section{Por Philip Meyer, traduzido por Manfred Matos}

O doutorado não goza de boa reputação no ensino do jornalismo e existem razões para tal.

Quando as escolas de jornalismo foram fundadas, na maior parte das vezes em universidades públicas do meio-oeste e sul, sua função primordial era providenciar mão de obra barata para a imprensa. Os administradores das universidades enxergaram o valor de Relações Públicas nesse papel - sem falar na possibilidade de que, eventualmente, alguns desses trabalhadores mal pagos poderiam ascender no meio profissional, tornando-se, a partir das posições de influência que viessem a ocupar, defensores das escolas que os formaram.

Durante a maior parte deste século, o meio impresso mudou tão lentamente que pareceu a seus participantes se manter em um estado estático. A inovação necessária restringiu-se ao aspecto tecnológico, fazendo com que a divulgação das notícias se tornasse mais rápida e eficiente. No entanto, as habilidades necessárias para produzir o produto editorial não mudaram, e o professor de jornalismo ideal era uma espécie de "artesão" da imprensa, capaz de compartilhar as habilidades aprimoradas em seu trabalho com os jovens que, por sua vez, voltariam ao mesmo mundo que o professor havia deixado.

O doutorado é um título conferido a quem realiza pesquisa, e um artesão que não vê a necessidade de mudança tampouco reconhece a necessidade concomitante de investigá-la.

Professores de jornalismo buscaram a motivação para produzir conhecimento novo a partir do "clima social" da academia - no qual o professor ideal não é definido apenas pela sua habilidade pedagógica, mas também pelas contribuições ao conhecimento de sua área -, pois não a receberam da indústria a que serviam.

Para preencher essa necessidade social na ausência de suporte financeiro por parte da indústria, professores de jornalismo e seus doutorandos viram-se forçados a desenvolver projetos engenhosos (devido às circunstâncias e aos parcos recursos), mas de alcance limitado, estudos experimentais com objetos de importância secundária, análises de conteúdo a partir de material adquirido com certa facilidade e breves questionários por e-mail. Esse foi o primeiro golpe desferido contra seus esforços para ganhar a legitimação da indústria. 
O segundo golpe está contido, por assim dizer, na especificidade do trabalho e da comunicação dos resultados científicos. Os pesquisadores acadêmicos mais talentosos trabalham em peças pequenas de grandes quebra-cabeças. Quando encontram peças suficientes, um padrão inteligível emerge e ilumina uma vasta área de conhecimento, que pode ser apreciada tanto por acadêmicos como praticantes da atividade. No entanto, as comunicações individuais a respeito das peças específicas dificilmente possuem interesse para outras pessoas que não os pesquisadores envolvidos no mesmo projeto.

Jornalistas estão acostumados a ler histórias. Uma história tem um problema, um conflito e uma resolução. Termina com uma sensação agradável de desfecho. Uma comunicação científica finaliza com incertezas e um apelo para pesquisas futuras. Um artigo acadêmico não é uma leitura prazerosa, a não ser que você já esteja seguindo o trabalho na área por certo período de tempo.

O terceiro golpe diz respeito ao uso do jargão técnico. Físicos e engenheiros não reclamam sobre o uso do jargão em seus comunicados técnicos. Isso economiza tempo, já que uma palavra substitui um parágrafo inteiro de explicações que o iniciado na área já domina. Mas jornalistas profissionais esperam que qualquer texto expositivo seja inteligível a pessoas leigas. Alguns chegam a negar a existência de um corpo de conhecimentos em suas áreas que seja tão esotérico a ponto de requerer termos técnicos.

Existem, certamente, esforços nobres em superar esses problemas e explicar a pesquisa acadêmica para a profissão. O livro de Leo Bogart, Preserving the Press, ilumina os esforços do antigo Newspaper Advertising Bureau para impulsionar o potencial mercadológico de jornais através da pesquisa. Gerald Stone codificou os esforços individuais de diversos pesquisadores num conjunto de temas em sua obra Examining Newspapers. E Keith Stam, com recursos da American Newspaper Publishers Association, esclareceu a conexão entre o senso de pertença a uma comunidade e o público leitor da imprensa, o que contribuiu para a base teórica do que hoje é chamado de jornalismo cívico. Entretanto, a maior parte dos pesquisadores com doutorado em comunicação não estabelecem boas relações com a indústria.

Isso está mudando.

Como a maioria das mudanças abrangentes, essa também nasceu da necessidade. A realidade estática da indústria noticiosa se perdeu definitivamente. Jornais não são mais um monopólio natural, o gatekeeper exclusivo entre publicitários do varejo e seus clientes. A rapidez da mudança tecnológica está nos tornando subitamente mais parecidos com as outra profissões.

Engenharia, medicina, administração de empresas, biblioteconomia - quase todas as profissões cujos cursos profissionais possuem também um âmbito de pesquisa geraram continuamente
Num futuro

próximo, os

jornalistas bem sucedidos terão

de entender

não apenas os

processos e efeitos

da comunicação

de massa e as

teorias que buscam

explicá-la, como

também dominar

as habilidades do

ofício, tais como

a redação, edição,

diagramação

e produção

Estudos em Jornalismo e Mídia - Ano VI - n. 2 pp. 219 - 222 jul./dez. 2009 
a necessidade de novos conhecimentos. Toda turma de graduandos de um curso de engenharia é visto com apreensão pelos profissionais de sua área, pois os jovens dispõe de conhecimento que os veteranos não possuem. Engenheiros sênior acabam em funções administrativas ou de vendas porque a tecnologia avança mais rápido do que sua capacidade de atualização.

As fontes dessa mudança têm sido pessoas com titulação em pesquisa, muitos delas em universidades. Você pode ou não estar preparado, isso está acontecendo conosco, mesmo no trabalho mais rotineiro. Jovens profissionais que conseguem criar páginas da web, digitalizar fotografias e fazer pesquisas eletrônicas estão sendo demandados precisamente porque possuem as habilidades que os mais experientes não tiveram tempo ou interesse em adquirir. Existe ainda a demanda por repórteres treinados para pesquisar em bancos de dados, com habilidades estatísticas e analíticas nunca apreendidas pelos veteranos.

Essas são evidentemente mudanças baseadas nos avanços tecnológicos. O próximo rol de mudanças não é assim tão evidente. Os valores do jornalismo têm sido guiados por uma realidade de mercado que assumiu a escassez da informação. $\mathrm{O}$ apelo poético de John Milton pela livre expressão, pela supressão das licenças necessárias à impressão dos conteúdos, pressupõe que a informação a respeito de qualquer assunto como algo de bom em si mesmo. Nossa época, marcada pela abundância de informação, está tensionando essa fórmula antiga. Hoje é a atenção, e não a informação, que pode ser vista como um bem raro. E mídias viabilizadas pela publicidade adotam estratégias bizarras para conseguir a sua fatia de atenção. Seguem dois exemplos:

- Apelando para o mau gosto ao promover obscenidades, violência e conteúdos profanos - mesmo nos horários que convencionamos chamar de familiares.

- Corrompendo notícias e produtos de entretenimento ao incluir neles mensagens comerciais, fazendo com que o usuário nunca saiba onde termina o trabalho do jornalista ou artista e onde começa o do vendedor.

De repente, o trabalho do jornalista é mais complicado do que apenas fornecer informação. Agora o problema não é apenas levá-la ao público. Devemos nos preocupar com o que lhe fornecemos. Num futuro próximo, os jornalistas bem sucedidos terão de entender não apenas os processos e efeitos da comunicação de massa e as teorias que buscam explicá-la, como também dominar as habilidades do ofício, tais como a redação, edição, diagramação e produção.

A tecnologia está nos forçando a um status profissional, independentemente se queremos ou não assumi-lo. Uma qualidade que distingue um profissional de um "artesão" é o conhecimento
A tecnologia está nos forçando a um status profíssional, independentemente

se queremos ou não assumi-lo. Uma qualidade que distingue um profissional de um "artesão" é - conhecimento da teoria, dos princípios que subjazem o ofício 
da teoria, dos princípios que subjazem o ofício. Um ofício é aprendido por imitação: assistir à performance de um mestre e depois imitá-la. Uma profissão é aprendida a partir de princípios fundamentais, de modo que quando as situações mudam, o profissional entende as mudanças e ajusta as técnicas para se adequar.

O ensino do jornalismo tem menos espaço para senhores como eu, que ensinam as antigas habilidades do ofício e fazem comentários acerca de como as coisas se comportavam quando estávamos no meio. O mundo deu voltas desde então. Atualmente, temos uma necessidade desesperada pela teoria, por novas maneiras de compreender o desenvolvimento midiático e as escolhas que somos forçados a fazer. Universidades com programas de pós-graduação consistentes são a nossa melhor esperança para desenvolver esse novo conhecimento.

Recebido em 16 de setembro de 2009

Aprovado em 17 de setembro de 2009 